\title{
Effect of Fermentation Time and Percentage of Moringa (Moringa oleifera) Flour Variations on Vitamin C of Yogurt
}

\author{
Martha Aznury ${ }^{1, *}$ Elina Margerty ${ }^{1}$ Melianti $^{1}$ Sofiah $^{1}$ Yuniar $^{1}$ Sufi Awwaliyah ${ }^{1}$ \\ ${ }^{1}$ Department of Chemical Engineering, Politeknik Negeri Sriwijaya, Palembang, Indonesia \\ ${ }^{*}$ Corresponding author. Email: martha_aznury@polsri.ac.id
}

\begin{abstract}
This study aims to determine the amount of lactic acid and ascorbic acid/vitamin C content of Moringa oleifera's yogurt. Effect of the concentration of Moringa leaf flour, respectively 0;3;5; and 7\%, while the fermentation time was 4,6 , and 8 hours. The raw material used are UHT's milk, with $10 \%$ of sugar and $3 \%$ of skimmed milk added. In this study, an organoleptic test was carried out to determine the level of consumer preference of Moringa oleifera's yogurt so that the concentration of moringa leaf's flour and the fermentation time was appropriate according to consumer preferences.
\end{abstract}

Keywords: Yogurt, Moringa Leaf, Lactic Acid, Vitamin C, Organoleptic

\section{INTRODUCTION}

The use of the basic ingredients of cow's milk in making yogurt can extend the usability and shelf life (Ola, 2017). In addition, the fermentation process in making yogurt can lactose content in yogurt to decrease (Syainah et al., 2017), so that it can be used as an alternative for people with lactose intolerance (Koswara, 2009).

Moringa (Moringaoleifera) is a type of vegetable that can be used to increase the nutritional content of a product in the form of food or beverages. Moringa leaves are often used by the community for foodmaking needs and as herbal medicine (Dhakar et al., 2011).

Moringa plants have been known throughout the world as a nutritious plant and WHO has introduced moringa as an alternative food to overcome nutritional problems. In Africa and Asia, Moringa leaves are recommended as a nutrient-rich supplement for breastfeeding mothers and children during their infancy (Kurniasih, 2013). According to Kurniasih (2013), the benefits and properties of the Moringa oleifera plant are mostly found in the leaves. Apart from being used as a vegetable, it is also used as a powder by drying and pounding it to be added to other types of food such as soup, gravy, biscuits, bread and cakes. In addition, the processing of dried moringa leaves is also used as an ingredient in moringa tea (brewed and dipped), fillers for capsules, and moringa tablets (Aminah et al., 2015). Moringa leaves contain various kinds of amino acids, including amino acids in the form of aspartic acid, glutamic acid, alanine, valine, leucine, isoleucine, histidine, lysine, arginine, venilalanine, triftopan, cysteine, and methionine (Simbolan et al., 2007).

Moringa leaves contain vitamin $\mathrm{C}$ which is quite high. Ascorbic acid or better known as vitamin $\mathrm{C}$ is a chemical compound that has the molecular formula C6H8O6. Vitamin $\mathrm{C}$ has high water solubility. In a dry state, vitamin $\mathrm{C}$ is quite stable, but when it dissolves, this vitamin is easily damaged by the oxidation process, especially when exposed to heat. Because it is very easily oxidized by heat, light and metals, vitamin $\mathrm{C}$ is included in the antioxidant group (Pakaya, 2014).

Antioxidant is a substance that stops or inhibits oxidative damage to a target molecule by reacting with reactive free radicals to form a relatively stable one. Antioxidants help stop the process of cell destruction by giving electrons to free radicals. Antioxidants will neutralize free radicals so that they no longer have the ability to steal electrons from cells and DNA (Murray, 2009). According to Parwata (2016), vitamin C is one type of natural antioxidant.

Yogurt with Moringa leaves can be said to have a strong combination because they both contain high calcium, protein and minerals (Ola, 2017). The addition 
of Moringa leaves to yogurt will certainly have an influence on the aroma, taste, texture and nutritional content of yogurt. Based on this description, the researcher wanted to conduct research on the effect of variations in the concentration of Moringa leaves and fermentation time on changes in levels of vitamin $\mathrm{C}$ contained in Moringa leaf yogurt. In addition to analyzing vitamin $\mathrm{C}$ levels, it is still necessary to adjust the quality standards and characteristics of yogurt nationally based on SNI (2981), 2009), including analyzing $\mathrm{pH}$ and acidity test by knowing the total amount of lactic acid contained in Moringa leaf yogurt. The research product will also be tested for organoleptic so that it is suitable for consumption by the wider community.

With the addition of Moringa leaf flour with several variations and fermentation time, is there any influence on ascorbic acid / vitamin C levels after fermentation into Moringa leaf yogurt and how long is the fermentation time and optimum concentration to produce Moringa leaf yogurt with high vitamin C content and in accordance with the SNI standards that have been determined.

In general, the bacteria that is often used in making yogurt are Streptococcus thermophilus and Lactobacillus delbrueckii ssp. Bulgaricus (Rahman et al., 2019). In yogurt, the bacteria Streptococcus thermophillus and Lactobacillus bulgaricus work together to form the taste and characteristics of yogurt. Streptococcus thermophilus bacteria ferment milk lactose and produce lactic acid and $\mathrm{CO} 2$ gas. The results of the metabolism of Streptococcus thermophilus bacteria then stimulate the growth of Lactobacillus bulgaricus bacteria that are tolerant of acidic conditions. While the results of the metabolism of Lactobacillus bulgaricus bacteria, namely amino acids and peptides, will stimulate the development of Streptococcus thermophilus bacteria (Bahtiar, 2008).

According to Effendi (2004), the fermentation process of lactic acid bacteria is influenced by several factors, including temperature, environmental conditions, and nutrients required by starter cultures. The fermentation temperature for making soyogurt and yogurt ranges from $37-45{ }^{\circ} \mathrm{C}$, after the precipitate is formed, it is immediately put into the refrigerator for about $4{ }^{\circ} \mathrm{C}$ so that the bacteria will be stunted. The environmental conditions of fermentation for making yogurt and soyghurt must support the formation of acid, so the degree of acidity $(\mathrm{pH})$ in the fermentation of making yogurt is 3.5-5. High acidity or low $\mathrm{pH}$ indicates that much of the lactose has been converted into lactic acid. The high and low levels of lactic acid in the product are influenced by the ability of the starter to form lactic acid used or determined by the amount and type of starter used. As for the nutrients required by starter cultures include carbohydrates (sugar), such as sucrose (sugar), glucose, lactose. and fructose or skimmed milk powder as an energy source, carbon and nitrogen providers (Ganjar et al., 2006). The ratio between Streptococcus thermophillus and Lactobacillus bulgaricusis 1:1 in order to produce the best properties and aroma of yogurt (Ghadge et al., 2008). The combination of the two cultures is better used in the yogurt production process than the use of a single culture (FAO / WHO, 1972).

\section{MATERIAL AND METHOD}

The study was designed using a factorial completely randomized design consisting of 2 factors, namely the percentage of moringa flour $(0,3,5$, and $7 \%)$ and fermentation time $(4,6$, and 8 hours). The process of making yogurt is based on research conducted by Prasetyo (2010) and modification by Kosikowski (1985). The organoleptic and analysis test are decided using SPSS software.

The materials used in this study were UHT cow's milk, Lactobacillus bulgaricusand Streptococcus Thermophillus, Moringa leaves, $1 \mathrm{~N} \mathrm{NaOH}$ Solution, KHP (Potassium Hydrogen Ptalat), Ascorbic Acid, Phenolptalein Indicator, and 1,1-diphenyl-2-pikrihiadzil (DPPH). The tool used to analyze the levels of vitamin $\mathrm{C}$ in this study was the UV-Vis Spectrophotometry (Agilent UV Vis 8453) with a wavelength of $265 \mathrm{~nm}$

Variabel of consentration Moringa fluor and fermentation time, see in Table 1.

Table 1 Variabel of concentration Moringa flour and fermentation time

\begin{tabular}{cccc}
\hline \multirow{2}{*}{ Cons. Moringa } & \multicolumn{3}{c}{ Fermentation time (hour) } \\
\cline { 2 - 4 } & $4(\mathrm{~T} 1)$ & $6(\mathrm{~T} 2)$ & $8(\mathrm{~T} 3)$ \\
\hline $0 \%(\mathrm{C} 1)$ & $\mathrm{C} 1 \mathrm{~T} 1$ & $\mathrm{C} 1 \mathrm{~T} 2$ & $\mathrm{C} 1 \mathrm{~T} 3$ \\
$3 \%(\mathrm{C} 2)$ & $\mathrm{C} 2 \mathrm{~T} 1$ & $\mathrm{C} 2 \mathrm{~T} 2$ & $\mathrm{C} 2 \mathrm{~T} 3$ \\
$5 \%(\mathrm{C} 3)$ & $\mathrm{C} 3 \mathrm{~T} 1$ & $\mathrm{C} 3 \mathrm{~T} 2$ & $\mathrm{C} 3 \mathrm{~T} 3$ \\
$7 \%(\mathrm{C} 4)$ & $\mathrm{C} 4 \mathrm{~T} 1$ & $\mathrm{C} 4 \mathrm{~T} 2$ & $\mathrm{C} 4 \mathrm{~T} 3$ \\
\hline
\end{tabular}




\section{RESULT AND DISCUSSION}

Analysis

The $\mathrm{pH}$ value of Moringa leaf yogurt for each treatment is shown by Figure 1 below :

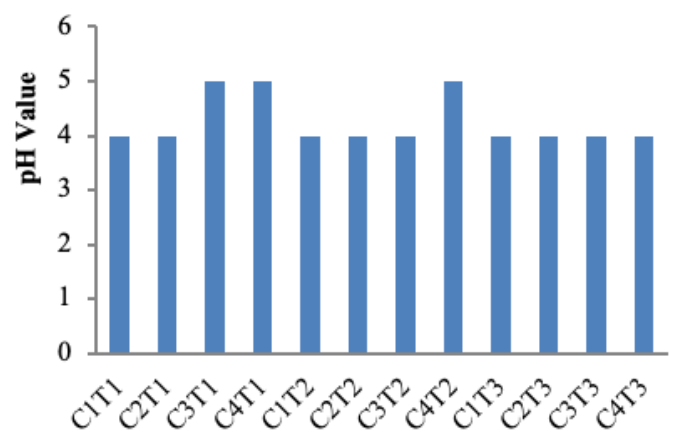

Treatment

- $\mathrm{pH}$ Value

Figure 1. Variabel of the $\mathrm{pH}$ value of Moringa leaf yogurt

Figure 1 shows the $\mathrm{pH}$ value of Moringa leaf yogurt for each treatment having a $\mathrm{pH}$ range of around 4-5. The $\mathrm{pH}$ value in the range $4-5$ can be said to be still safe because it meets SNI for yogurt, namely the $\mathrm{pH}$ value must be around 3.5-5. In the treatment of Moringa leaf yogurt with a fermentation time of 4 hours, with different concentrations of Moringa leaves, a concentration of $0 \%$ and $3 \%$ had a $\mathrm{pH}$ of 5 . At a concentration of $5 \%$ and $7 \%, \mathrm{a} \mathrm{pH}$ value of 4 .In the treatment of Moringa leaf yogurt with time fermentation of 6 and 8 hours, with different concentrations of Moringa leaves, at a concentration of $0 \%, 3 \%$, and $5 \%$ have a $\mathrm{pH}$ of 4 , and at a concentration of $7 \%$ have a $\mathrm{pH}$ value of 5 . By carrying out the fermentation process, the $\mathrm{pH}$ value obtained is -Each treatment decreased, which means that the Moringa leaf yogurt sample has acidic properties. If the $\mathrm{pH}$ value is high, the acidity level will be lower, whereas if the $\mathrm{pH}$ is low, the acidity level will be higher.

According to Zakariya, et al., (2013) during fermentation, lactic acid bacteria will degrade milk lactose into lactic acid, thereby reducing $\mathrm{pH}$ levels. The longer during fermentation, the formed lactic acid will be secreted out of the cells and accumulate in the fermentation medium so that the longer the fermentation time, the total amount of accumulated acid increases and decreases the $\mathrm{pH}$ (Kartikasari, 2014).

\section{Lactic Acid Test Analysis}

The total acid value obtained from different variation in concentration treatment and fermentation time shown by Figure 2 :

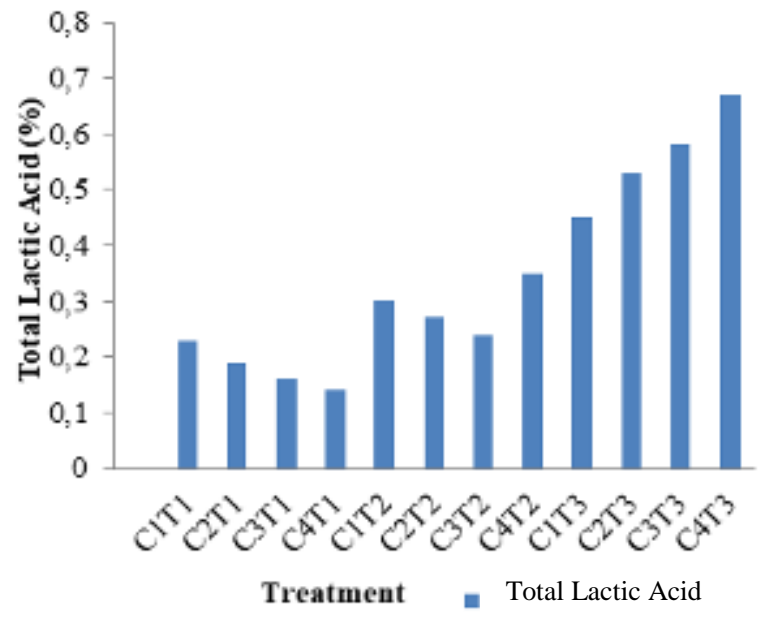

Figure 2.Chart of Sample Treatment to the Total value of Lactic Acid Moringa Leaf Yogurt

Figure 2 shows that the total acid value obtained was different with the variation in the concentration treatment and fermentation time. In the sample of C4T3 Moringa leaf yogurt with a concentration of $7 \%$, the total value of lactic acid was higher than the concentrations of 0,3 , and $5 \%$ in the 8 hour fermentation time. These results indicate a relationship, namely the higher the concentration of Moringa leaves, the higher the total acidity value of the yogurt. The factor that affects the high value of the total acidity of yogurt is the amino acid content (Bahtiar, 2008). The content of amino acids, namely histidine in Moringa leaves, is one of the factors that causes a high total acid value because it can trigger the growth of Lactobacillus bulgaricus. Amalia (2002) states that Lactobacillus bulgaricusstimulates Steptococcus thermophillus by releasing the amino acids glycine and histidine in the growth medium, in other words Lactobacillus bulgaricusprovides essential nutrients for the growth of Streptococcus thermophillus so that Streptococcus thermophillus can lower the $\mathrm{pH}$ which will also stimulate the growth of Lactobacillus. bulgaricus continues to grow and produces lactic acid. The higher the concentration of Moringa leaves added to yogurt, the higher the amino acid content of histidine in the fermentation process, so the greater the lactic acid content produced by Streptococcus thermophillus bacteria as a result of being stimulated by these amino acids.

According to the National Standard Agency (2009), the SNI quality requirements for the acidity of yogurt range from $0.5-2.0 \%$. The total yogurt lactic acid obtained in this study ranged from 0.13 to $0.67 \%$. Based on the results of the total acid value, there are several samples that meet the quality standards, namely samples C1T3, C2T3, C3T3, and C4T3 whose values are in the range of $0.5-2.0 \%$. It can be seen that the fermentation time that produces the highest total acid value and is in 
accordance with the quality requirements is at 8 hours. According to Septiani et al., (2013), the longer the fermentation time, the more acidic bacteria will produce acid, and the higher the acid is formed. At the fermentation time of 4 and 6 hours, the total lactic acid that did not meet the quality requirements was obtained, with a range of $0.23-0.35 \%$. The total lactic acid obtained did not meet the quality requirements due to low microbial activity because the substrate content that was formed was still small (Amaliah, 2002).

\section{Vitamin C Content Analysis}

The vitamin $\mathrm{C}$ content obtained from different variation in concentration treatment and fermentation time shown by Figure 3 .

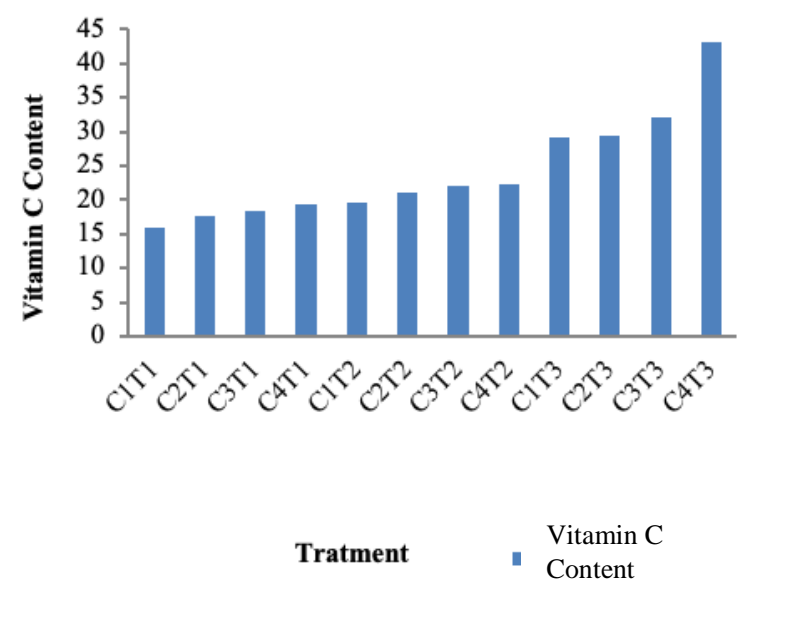

Figure 3.Chart of Sample Treatments on Vitamin C Levels in Moringa Leaf Yogurt

Figure 3 shows that each treatment had a significant effect and different results on the vitamin C content of the Moringa leaf yogurt sample. It can be seen that samples with higher concentrations, namely C4T1, C4T2, and C4T3 have a higher vitamin C content at variations in the fermentation time of 4,6 and 8 hours, respectively, this is due to the content of Moringa leaves already contain quite high vitamin $\mathrm{C}$ before fermentation is carried out and it turns out to have a fairly good resistance and is not easily oxidized during the fermentation process. According to Krisnadi (2015), the ascorbic acid / vitamin $\mathrm{C}$ content of fresh Moringa leaves is $51.7 \mathrm{mg}$ in 100 grams. Apart from fermentation time, temperature also plays an important role during the fermentation process. If the temperature is not in accordance with the provisions of fermentation, then the level of vitamin $\mathrm{C}$ is not guaranteed to be contained in sufficient quantities in Moringa leaf yogurt. In this study of moringa leaf yogurt, the temperature during the fermentation process was $35{ }^{\circ} \mathrm{C}$. The resistance of moringa yogurt to heat is discussed in Pakaya's (2014) statement, that vitamin C is easily damaged by the oxidation process, especially when exposed to heat

\section{Organoleptic Test}

\section{A. Color Preference Test}

The color organoleptic test was accumulated from the 15 panelists tested to choose their tendancies towards the samples and decided based on ANOVA and Duncan test using SPSS software, shown by figure 4 .

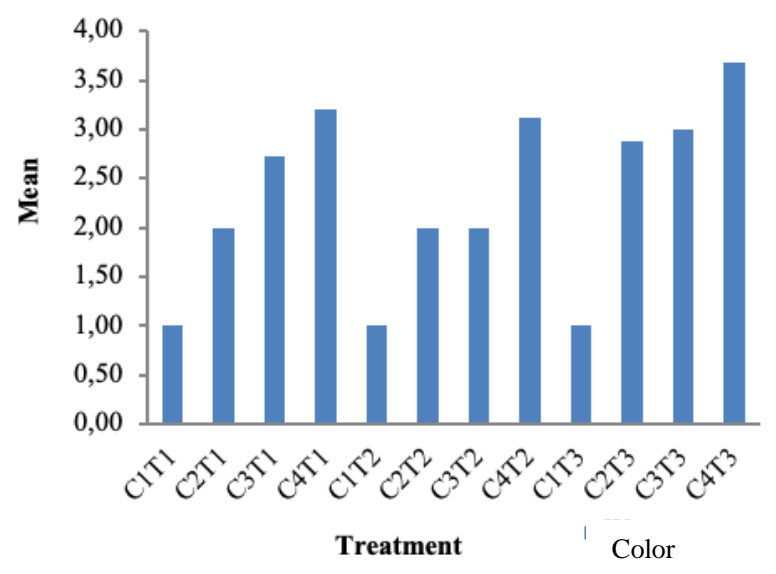

Figure 4.Chart of Color Organoleptic Test Result of Moringa Leaf Yogurt

Based on the results of the color organoleptic test, panelists tended to on average choose Moringa leaf yogurt with a percentage of $5 \%$ with a fermentation time of 8 hours. The higher concentration treatment had the greener yogurt and moringa, these samples were samples of C4T1, C4T2, and C4T3. Winarno (2002) states that a material is assessed for its nutrition, good taste, excellent texture and attractive colors that will be liked by the public. Moringa leaf yogurt has a characteristic green color, because the characteristic color of the moringa leaves is green. Thus, the more the amount of moringa leaf extract is added, the color of the resulting yogurt will get darker. The addition of Moringa leaf extract has an effect on the color of yogurt because Moringa leaves contain chlorophyll compounds. According to Krisnadi (2012) Moringa leaves contain chlorophyll or green pigment found in green vegetables. The chlorophyll content in dried moringa leaves is $162 \mathrm{mg}$ per 8 grams. Thus, in 30 grams of Moringa leaf extract, there are $4,860 \mathrm{mg}$ or 4.9 grams of chlorophyll.

\section{B. Aroma Preference Test}

The aroma organoleptic test was accumulated from the 15 panelist tested to choose their tendancies towards the samples and decided based on ANOVA and Duncan test using SPSS software, shown by figure 5: 


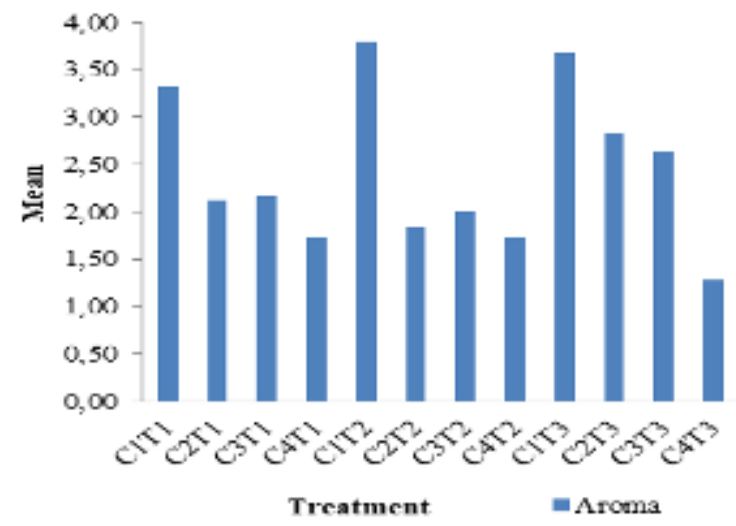

Figure 5. Chart of Aroma Organoleptic Test Result of Moringa Leaf Yogurt

Based on the results of the organoleptic aroma test, panelists tended to on average choose Moringa leaf yogurt at a percentage of $3 \%$. This is because the sample is given a fermentation time of 8 hours, in which the fermentation time in this study is the longest. Moringa leaf yogurt still has the distinctive aroma of yogurt. The distinctive aroma of yogurt is caused by lactic acid and acetacdehyde compounds, diacetyl, acetic acid produced during fermentation by the bacteria Lactobacillus bulgaricus(Triyono, 2010). Aminah's statement (2012) also supports that the fermentation process creates the distinctive taste of yogurt and determines the quality of the yogurt. The addition of Moringa leaf extract which affects the aroma of yogurt is due to the fact that Moringa leaves contain lipoxidase enzymes, this enzyme is found in green vegetables because the lipoxidase enzymes hydrolyze or break down fat into compounds that cause unpleasant odors, which belong to the hexanal 7 and hexanol groups (Santoso, 2005). This unpleasant smell can be reduced by blanching (quick dip).

\section{Flavor Preference Test}

The flavor organoleptic test was accumulated from the 15 panelist tested to choose their tendancies towards the samples and decided based on ANOVA and Duncan test using SPSS software, shown by figure 4

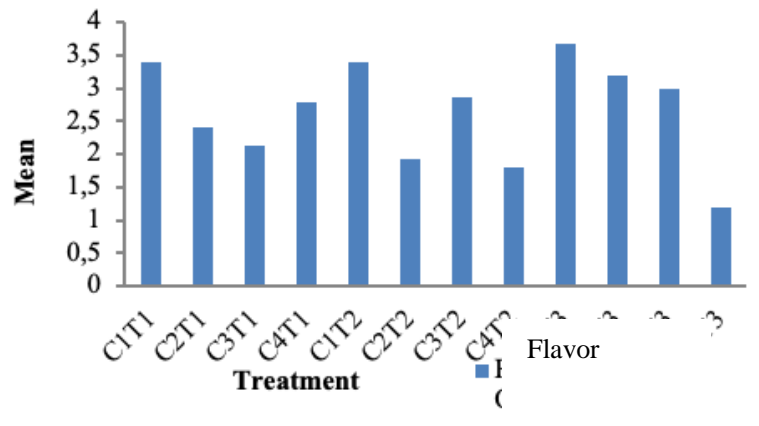

Figure 6.Chart of Flavor Organoleptic Test Result of Moringa Leaf Yogurt
Based on Figure 6, from the results of the organoleptic test for the flavor of Moringa leaf yogurt on 15 panelists, it was found that the taste that was considered the most preferred was Moringa leaf yogurt with a percentage of Moringa leaf flour of 3\%. Moringa yogurt has a sour taste (according to the characteristics of yogurt). In yogurt with a high percentage of Moringa leaf flour, the sour taste that is owned is not too acidic, where in the sample the concentration of treatment given is high, namely $3 \%$. This is because the taste of Moringa leaves dominates the yogurt, so that the acidity of the yogurt is reduced.

\section{Aroma Preference Test}

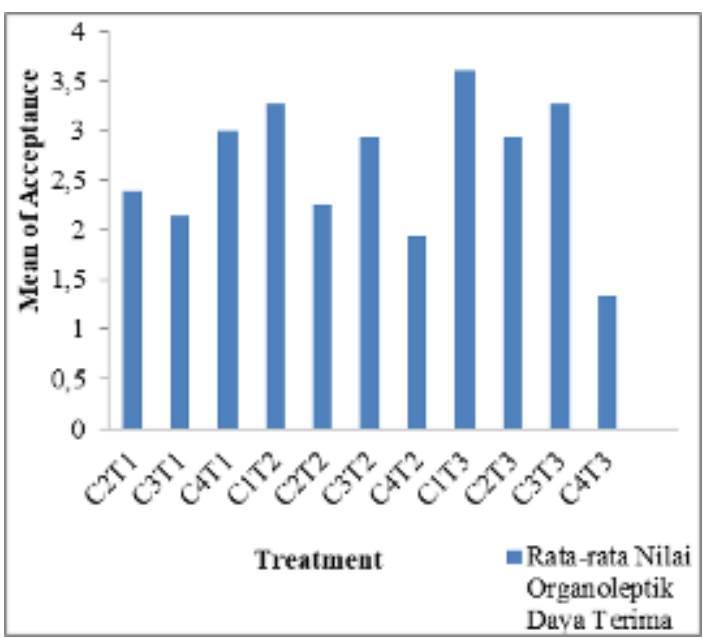

Figure 7.Chart of Acceptance Organoleptic Test Result of Moringa Leaf Yogurt

Based on Figure 7, the results of the organoleptic test in the form of sample acceptance for 15 panelists, it was found that the preferred sample of the panelists was the C3T3 sample, which had a higher panelist tendency value. The sample that was not liked by the panelists was the C4T3 sample with a higher concentration of Moringa leaves and fermentation time.

From the overall organoleptic results, panelists tended to give the highest score on samples $\mathrm{C} 2 \mathrm{~T} 3$ and C3T3. The treatment on these samples may be recommended for Moringa leaf yogurt products that can be enjoyed by the wider community.

\section{E. Comparisons with Previous Researches}

To assess the results of the present study, a comparison was made with the results of previous studies. Comparison of current research results with previous research results can be seen in Table 2 below: 
Tabel 2.Comparisons with Previous Researches

\begin{tabular}{|c|c|c|c|c|c|c|c|c|}
\hline \multirow[b]{2}{*}{ Formulasi } & \multicolumn{3}{|c|}{ Treatments } & \multicolumn{4}{|c|}{ Name of Tests } & \multirow[b]{2}{*}{$\begin{array}{l}\text { Referensi } \\
\text { Penelitian }\end{array}$} \\
\hline & $\begin{array}{c}\text { Material } \\
\text { Fortification }\end{array}$ & $\begin{array}{l}\text { Fermentation } \\
\text { Time }\end{array}$ & $\mathrm{pH}$ & $\begin{array}{l}\text { Total } \\
\text { Lactic } \\
\text { Acid } \\
(\%)\end{array}$ & $\begin{array}{l}\text { Vitamin } \\
\text { C } \\
\text { Content } \\
(\mathrm{mg})\end{array}$ & $\begin{array}{l}\text { Fat } \\
\text { Content } \\
(\%)\end{array}$ & $\begin{array}{l}\text { Ash } \\
\text { Content } \\
(\%)\end{array}$ & \\
\hline $\begin{array}{l}\text { L. Bulgaricus\& S. Thermophillus } \\
\text { Bacteria }\end{array}$ & $\begin{array}{l}\text { Cococnut } \\
\text { Liquid } 75 \\
\text { ml+ } \\
\text { Extract of } \\
\text { Soursop } 75 \\
\text { ml } \\
\text { Moringa }\end{array}$ & 12 Hours & ND & ND & 16 & ND & ND & Septiyani (2013) \\
\hline $\begin{array}{l}\text { L. Bulgaricus\& S. } \\
\text { ThermophillusBacteria }\end{array}$ & Flour $=6 \%$ & 16 Hours & 4 & ND & ND & ND & ND & Aznury (2019) \\
\hline $\begin{array}{l}\text { L. } \\
\text { Bulgaricus,Bifidobacteriumlactis, } \\
\text { Lactobacillus } \\
\text { acidophilusBacteria( } 2 \%)\end{array}$ & $\begin{array}{l}\text { Water }= \\
60 \%\end{array}$ & 18 Hours & 3,86 & ND & ND & & & \\
\hline $\begin{array}{l}\mathrm{CO} 2=8 \text { gram } \\
\text { L. Bulgaricus\& S. Thermophillus } \\
(3 \%) \text { Bacteria }\end{array}$ & $\begin{array}{l}\text { Extract of } \\
\text { Corn }\end{array}$ & 24 Hours & 3,82 & 1,63 & ND & 2,22 & 0,91 & $\begin{array}{l}\text { Burton (2014) } \\
\text { Diputra (2014) }\end{array}$ \\
\hline \multicolumn{9}{|l|}{ SkimMilk $(12,5 \%)$} \\
\hline $\begin{array}{l}\text { L. Bulgaricus\& S. Thermophillus } \\
\text { Bacteria }\end{array}$ & $\begin{array}{l}\text { Extract of } \\
\text { Soursop } \\
(100 \mathrm{ml})\end{array}$ & 12 Hours & ND & ND & $20 \mathrm{mg}$ & ND & ND & Selibata (2017) \\
\hline $\begin{array}{l}\text { L. Bulgaricus\& S. Thermophillus } \\
\text { Bacteria }(3 \%)\end{array}$ & $\begin{array}{l}\text { Moringa } \\
\text { Flour }=3 \%\end{array}$ & 8 Hours & 4 & 0,5876 & 21,99 & ND & ND & This Research \\
\hline \multicolumn{9}{|l|}{ Skim Milk (3\%) } \\
\hline $\begin{array}{l}\text { Sugar (10\%) } \\
\text { Bakteri L. Bulgaricus\& S. } \\
\text { Thermophillus(3\%) }\end{array}$ & $\begin{array}{l}\text { Moringa } \\
\text { Flour }=5 \%\end{array}$ & 8 Hours & 4 & 0,5267 & 30,04 & ND & ND & This Research \\
\hline \multicolumn{9}{|l|}{ Skim Milk (3\%) } \\
\hline Sugar (10\%) & & & & & & & & \\
\hline
\end{tabular}

From Table 1, with previous yogurt research, comparisons can be made with different types of treatment and test results. In research conducted by Aznury (2019), Burton (2014) and Diputra (2014), each obtained a $\mathrm{pH}$ value of 5 ; 3.86; and 3.82. Research conducted at this time, with a concentration of Moringa leaves, respectively 3 and 5\%, obtained a $\mathrm{pH}$ value of 4 . The $\mathrm{pH}$ value of yogurt shows the level of acidity of the yogurt. The lower the $\mathrm{pH}$ value obtained, the higher the acidity level of the yogurt. Based on the results of the comparison of each study, the $\mathrm{pH}$ value of research yogurt is currently considered quite low and still meets SNI standards (2009), namely in the range 3.5-4.5 so it is still safe for consumption.

This study found that the total levels of lactic acid were 0.5876 and $0.5267 \%$. Diputra (2014) with the addition of corn extract to yogurt by $1.63 \%$ total lactic acid treatment. Both of these studies still meet the standard value of yogurt according to SNI (2009), which ranges from $0.5-2.0 \%$ so it is still safe for consumption.

Based on research conducted by Septiyani (2013), the level of vitamin C obtained was $16 \mathrm{mg}$, and in Selibata's research (2017) it was found that vitamin C levels were $20 \mathrm{mg}$. Research conducted now, with the addition of $3 \%$ and $5 \%$ moringa leaf flour and 8 hours of fermentation time, the vitamin $\mathrm{C}$ levels obtained were greater than the research conducted by Septiyani (2013) and Selibata (2017), namely 21 respectively. $99 \mathrm{mg}$ and $30.04 \mathrm{mg}$. Based on the results of the comparison of these studies, it can be said that yogurt with the addition of Moringa leaf flour with fermentation for 8 hours has a large enough vitamin $\mathrm{C}$ content. From the comparison of the research's vitamin $C$ levels, current research is considered to be able to further increase the nutrition content of the vitamin $\mathrm{C}$ content of yogurt.

\section{CONCLUSION}

Based on the research of Moringa leaf yogurt by giving treatment of variations in the concentration and time of fermentation treatment of Moringa leaf yogurt, it can be concluded that in terms of all the data used in this study, from all samples, treatment of $\mathrm{C} 2 \mathrm{~T} 3$ and $\mathrm{C} 3 \mathrm{~T} 3$ with a concentration of $3 \%$ and $5 \%$ and fermentation time 8 jam has a fairly high level of vitamin $\mathrm{C}$ and has a higher level of preference.

\section{REFERENCES}

[1] Amaliah, A. (2002). Pembuatan Soygurt Dengan Media Ekstrak Tempe. Jakarta: Skripsi S1 Institut Pertanian Bogor 
[2] Aminah, Syarifah; Tezar Ramadhan; dan Mufliahni Yanis. (2015). Kandungan nutrisi dan sifat fungsional tanaman kelor (Moringa oleifera). Buletin Pertanian Perkotaan, 35-44.

[2] Bahtiar, B. (2008). Kefir Minuman susu fermentasi. Jakarta: PT Gramedia Pustaka Umum.

[3] Badan Standardisasi Nasional. (2009). SNI Yoghurt (SNI 2981:2009). Jakarta: Dewan Standardisasi Nasional.

[4] Dhakar, Ram C., Maurya, Sheo D., Brijendra, K Pooniya., Narendra, Bairwa., Manisha, Gupta., dan Sanwarmal. (2011). Moringa: The herbal gold to combat malnutrition. Cronicles of Young Scientists: India.

[5] FAO/WHO. 1972. Report of Joint FAO/WHO Expert Commitee on the Code of Principles Concerning Milk and Milk Products.

[6] Effendi, Supli. (2012). Teknologi Pengolahan dan Pengawetan Pangan. Bandung : Alfabeta.

[7] Ganjar, I, dkk. (2006) Mikologi Dasar dan terapan. Jakarta : Yayasan Obor Indonesia.

[8] Santoso, Gempur. (2005). Metodologi Penelitian Kualitatif dan Kuantitatif. Jakarta: Prestasi Putaka.

[9] Ghadge, P,N., K Prasad, dan P.S Kadam. (2008). Effect of fortification on the phsyco-chemical and sensoryproperties of buffalo milk yogurt. Electron J Environ Agric Food Chem (5): 2890-2899.

[10] Jay, Fahey W (2005). Moringa oleifera : A review of the Medical Evidence for its Nutritional, Therapeutic dan Prophylactic Properties Trees For Life Journal, 1-5.

[11] Kartikasari, D.I, Nisa, F. C. 2014. Pengaruh penambahan sari buah sirsak dan lama fermentasi terhadap karakteristik fisik dan kimia yoghurt. Jurnal Pangan dan Agrobisnis.

[12] Kosikowski, Frank., (1997).,Cheese and Fermented Milk Foods, Volume 1. University of Wisconsin : Madison.

[13] Koswara, S. (2009). Teknologi Pembuatan Yoghurt. EbookPangan.com,5-14.

[14] Kurniasih. (2013). Khasiat dan Manfaat Daun Kelor Untuk Penyembuhan Berbagai Penyakit. Yogyakarta: Pustaka Baru Press.

[15] Krisnadi, A,D, (2015)., Kelor Super Nutrisi, Blora: Kelorina.com

[16] Malaka, R., (2007). Ilmu dan Teknologi Pengolahan Susu. Makasar: Yayasan Citra Emulsi.
[17] Murray R. K., Granner D.K., Mayes P.A., Rodwell V.W. (2003). Harper's Ilustrates biochemistry, 26th Ed. New York: McGraw-Hill.

[18] Nurjannah, Anang.,Yoyok, Ahmad., dan Setya., (2014), Total Asam Bakteri Asam Laktat, pH, Keasaman, Citarasa, dan Kesukaan Yogurt Drink dengan Penambahan Ekstrak Buah Belimbing. Jurnal Aplikasi Teknologi Pangan Universitas Dipeonegoro, Semarang.

[19] Ola, A. P. (2017). Pengaruh Variasi Konsentrasi Sari daun Kelor (Moringa oleifera) Terhadap Hasil Uji Organoleptik dan Kandungan Vitamin A pada Yoghurt Susu Sapi. Yogyakarta: Fakultas Keguruan dan Ilmu Pendidikan Universitas Senata Dharma.

[20] Pakaya, (2016). Nutritional and Phytochemical Composition of Moringa oleifera Lam and its Potential Use as Nutraceutical Plant. Pakistan Journal of Nutrition: 397- 405.

[21] Parwata, I Made O,A. (2016). Antioksidan. Kimia Terapan : Universitas Udayana.

[22] Prasetyo, H, (2010). Pengaruh Penggunaan Starter Yogurt pada Level Tertentu terhadap Karakteristik Yogurt yang Dihasilkan. Fakultas Pertanian, Universitas Sebelas Maret : Surakarta.

[23] Rahman, Ika, R., Nurkhasanah, dan Ika Kumalasari.., (2019). Optimasi Komposisi Lactobacillus bulgaricusdan Streptococcus thermophillus pada Yogurt Terfortifikasi Buah Lakum (Cayratia trifolia (L.) Domin) sebagai Antibakteri terhadap Esheria coli. Universitas Ahmad Dahlan: Yogyakarta.

[24] Simbolan, J.M; M. Simbolan, N, Katharina (2007). Cegah Manutrisi dengan Kelor. Kanisius, Yogyakarta.

[25] Surajudin, Kusuma, F.R., F. R Purnomo, dan Dwi., (2006). Yogurt Susu Fermnetasi yang Menyehatkan. Agromedia Pustaka, Jakarta.

[26] Syainah, Ermina; Sari Novita; dan Rusmini yanti. (2014). Kajian Pembuatan Yogurt Dari Berbagai Jenis Susu Dan Inkubasi Yang Berbeda Terhadap Mutu Dan Daya Terima. Jurnal Skala Kesehatan.

[27] Tamime, A, Y., dan V.M.E Marshall., (2007). Microbiological and Technological Aspects of Milks Fermented by Bifidobacteria, Journal of Dairy Research: 246

[28] Triyono, Agus (2010). Mempelajari Pengaruh Penambahan Beberapa Asam Pada Proses Isolasi Protei Terhadap Tepung Protein Isolat Kacang 
Hijau (Phaseolus radiates L.). Seminar Rekayasa Kimia dan Proses. ISSN:

[29] Zakaria, Yusdar., Yurliasni., Mira Delima., dan Ely Diana. (2013). Analisa Keasaman dan Total
Bakteri Asam Laktat Yogurt Akibat Bahan Baku dan Persentase Lactobalcillus casei yang berbeda. Jurusan Peternakan, Fakultas Pertanian Universitas Syiah

Kuala 